Wellhouse NHS Trust, Barnet General Hospital, Barnet, Herts EN5 3DJ, United Kingdom M R Whitlock

Correspondence to: M R Whitlock.

Accepted for publication 2 December 1998

\title{
Injuries to riders in the cross country phase of eventing: the importance of protective equipment
}

\author{
Michael R Whitlock
}

\begin{abstract}
Objectives-To determine the distribution of injuries in the eventing discipline of equestrian sports and the effectiveness of the protective equipment worn.

Methods-Data on all injuries sustained in the cross country phase over fixed obstacles were collected from 54 days of competition from 1992 to 1997 . This involved 16940 rides.

Results-Data on a total of 193 injuries were collected, which included two deaths. This represents an injury rate of $1.1 \%$. Head and facial injuries represented the largest group (31\%), with one third of these requiring treatment in hospital. All riders were wearing protective helmets and body protectors.

Conclusions-Eventing is one of the most dangerous equestrian sports. Improved protective equipment, which is mandatory for 1999 , should reduce the severity of these injuries.

(Br F Sports Med 1999;33:212-214)
\end{abstract}

Keywords: horse riding; eventing; protective equipment

Horse riding is known to be a dangerous pursuit, with an average of 16 deaths a year registered between 1982 and 1992. ${ }^{1}$ Avery et al noted that there were 98 deaths from horse related injuries between 1982 and 1998 compared with 86 for motor sports. Other studies have found that equestrian injuries amount to $4.3 \%$ of all sports related injuries. ${ }^{3}$ Eventing is becoming increasingly more popular. Over 150 horse trials were run in England in 1997, with more fixtures organised each year. ${ }^{4}$

In professional riding, jockeys have an estimated $2.5 \%$ injury rate. ${ }^{5}$ The wearing of a protective helmet has helped to reduce the severity of injuries. ${ }^{67}$ Fox hunting in North America has been considered to be no more dangerous than other types of riding, despite no protective helmets being used by most riders. $^{8}$

Head injuries have always been of concern, and several previous studies have highlighted this. ${ }^{9-11}$ Barber $^{12}$ noted that many of the riders admitted to hospital for a head injury in Oxford were not wearing any form of helmet. When this survey was repeated by Chitnavis et $a l^{13} 20$ years later there was a decrease in the number of admissions following a head injury, and this was thought to be due to more of the riders wearing a helmet. In eventing it has been mandatory to wear a helmet that conforms to Bs4472, similar to that for professional jockeys. ${ }^{14}$ The design has been criticised as not offering enough protection, ${ }^{15}$ and the standard was amended in $1988 .{ }^{16}$ After six deaths in eventing in 1993, four from a head injury, efforts have been made to improve the design of the helmet. For the 1998 season, the British Horse Trials Rule Book ${ }^{17}$ has made it mandatory to wear a helmet to the specification PAS $015^{18}$, the standard CEN $1984,{ }^{19}$ or any other protective headgear as may reasonably be expected to offer a similar, or higher, level of protection.

The wearing of a body protector has been controversial since the introduction of a standard in $1991 .^{20}$ The Irish Jockey Club have noted fewer rib fractures since its introduction (Hayley M, personal communication), but as the main function is to reduce soft tissue injury, it has been difficult to quantify its effectiveness. The standard has also been amended several times, but a new European standard for body and shoulder protectors was published in $1998 .^{21}$ This will offer several classes of protection, related to the energy absorption of the material used.

There is no published detailed analysis on the number of injuries in eventing, although there is a voluntary reporting system for medical officers. ${ }^{22}$ This study has investigated the number of injuries to event riders in England, before the introduction of improved safety equipment. A further study will be required to confirm whether the safety equipment reduces the injury severity.

\section{Methods}

The author attended as medical officer at 54 days of horse trials from 1992 to 1997. This involves several phases such as dressage, show jumping, and cross country which involves jumping over fixed obstacles. Personal experience has shown that the last of these produces most of the injuries. The standard of competition ranged from pre-novice to advanced Concors Complet International (CCI) events. This standard referred to the ability of the horse, and not necessarily that of the rider. Some of 


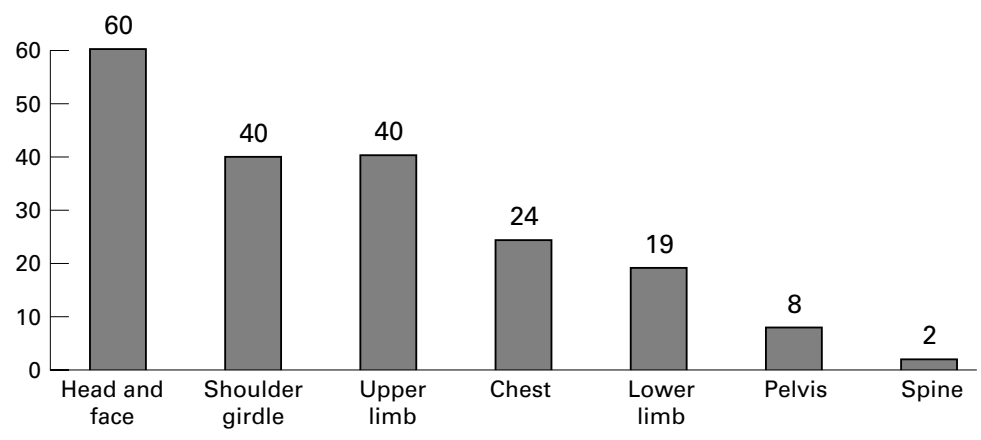

Figure 1 Anatomical distribution of eventing injuries.

the riders would compete with one horse in a novice class, for instance, and a different horse in the advanced section on the same day.

The criterion for an injury was that the rider required medical assistance and was considered unfit to continue riding that day. Hospital records were obtained in relevant cases, but no attempt was made to determine the final outcome. Injuries in the other phases of the competition, such as show jumping, were excluded.

\section{Results}

In the 54 days of cross country, 16940 horses competed. There were 193 injuries and two deaths. This represents an injury rate of $1.1 \%$ per ride. Both of the deaths occurred in a CCI event, the highest level of the competition. One death was due to a head injury sustained when the horse fell on top of the rider, and the other was due to massive chest injuries incurred also when the horse fell on the rider.

Figure 1 shows the anatomical distribution of the injuries. Most of the injuries were to the head and face $(31.1 \%)$, with the shoulder girdle being second in frequency $(20.7 \%)$. Twenty four riders were admitted to hospital, 20 with a head injury. Fifty five of the riders with a head injury were wearing a helmet to Bs4472 standard and five to the PAS015 specification. In two cases the rider was wearing a PAS015 helmet when the horse fell, crushing the head. Both riders were admitted to hospital and discharged within 24 hours.

There were two fractures to the spine, due to direct impact falls on to the ground. One case involved a fracture of T12, as well as several fractures to the transverse processes of the lumbar vertebrae. No riders were partially or permanently paralysed. No soft tissue injuries to the neck were recorded, although it was known that some riders were unable to ride the next day because of neck pain.

All riders were wearing a body protector to a BETA standard, but none of those who sustained a shoulder girdle injury were wearing a shoulder protector to any standard. In comparison there were 20 falls where the rider was wearing a shoulder protector to CEN class 3 standard. These were witnessed falls where the rider might be expected to have sustained a severe injury, but all were able to continue the competition.

\section{Discussion}

The results show that there were a large number of head and shoulder injuries, and protection to these areas should be given a high priority. The helmet is designed to withstand direct impacts and not from the rotational element of a head injury. When the Bs4472 standard was amended in 1988 to improve coverage around the sides, the manufacturers produced a more flexible lightweight helmet which was less likely to withstand crush injuries. Although rare, a crush injury, where the horse rolls on the rider, often has a fatal result. Some situations, in which the rider was wearing the more rigid PAS015 helmet, suggest that the severity of injury was reduced, but further studies will be needed to see if the overall severity of head injuries will be reduced by wearing this type of helmet. The PAS015 committee has already noted these findings, and has proposed a modification of the specification to include a simple lateral deformation test. $^{23}$ This will ensure that the helmet will be able to withstand some of the crushing effect when a horse rolls on top of the rider's head.

In all cases the rider was wearing some form of body protector, yet 24 chest injuries were recorded, one fatal. The protector is still in the developmental phase and has been improved every year. It is designed to reduce soft tissue injury and possibly provide some protection to the chest and spine from a fall or kick. It may also reduce the severity of injury from a kick to the upper abdomen. No rider who sustained a chest or spinal injury was wearing a protector that conformed to the BETA Class 3 or prEN 13158 standard. It is only when riders wear such garments that an accurate evaluation will be possible. Shoulder protectors have only been recently introduced as part of the standard. There have, however, been 20 witnessed falls where a shoulder injury was expected and the rider was wearing a shoulder protector. In all instances the rider was able to continue the competition. None of the riders who sustained a fracture to the shoulder girdle was wearing any form of protection to that area.

This paper has emphasised the importance of using the highest possible level of safety equipment in the cross country phase of eventing. This is reflected in the requirements for the wearing of helmets in competitions in the United Kingdom, under British Horse Trials Rules. It does not, however, insist on class 3 body protectors, nor shoulder pads. For international competitions, held in the United Kingdom and abroad, the requirements for wearing helmet and body protectors are lower. Perhaps the International Equestrian Federation should consider changing them, in view of the potential risks for riders.

1 Office of Population Censuses and Surveys. Fatal accidents occurring during sporting and leisure activities, 1982-92. Documents DH4 84/3-93/3.

2 Avery JG, Harper P, Ackroyd S. Do we pay too dearly for our sport and leisure? Public Health 1990;1046:417-23.

3 Lloyd RG. Riding and other equestrian injuries: considerable severity. Br f Sports Med 1987;21:22-4.

4 British Horse Trials Association. Bulletin and Omnibus schedule 1998. Stoneleigh, Warwickshire. 
5 Press JM, Davis PD, Weisner SI, et al. The National Jockey Injury Study: an analysis of injuries to professional horse racing jockeys. Clinical fournal of Sports Medicine 1995;4: 236-40.

6 D'Abreu F. Brain damage in jockeys. Lancet 1976;1:1241

7 Whitlock M, Whitlock J, Johnson B. Equestrian injuries: a comparison of professional and amateur injuries in Berkshire. Br f Sports Med 1987;21:25-6.

8 Harrison CS. Fox hunting injuries in North America. Physician and Sportsmedicine 1984;12:130-7.

9 Brooks WH, Bixby-Hammett DM. Head injuries in equestrian sports. Physician and Sportsmedicine 1983;11:82-6.

10 Ilgren EB, Teddy PJ, Vafadis J, et al. Clinical and pathological studies of brain injuries in horse-riding accidents: description of cases and review with a warning to the unhelmeted. Clin Neuropathol 1984;3:253-9.

11 Muwanga LC, Dove AF. Head protection for horse riders: cause for concern. Archives of Emergency Medicine 1985;2: cause 8 .

12 Barber HM. Horseplay: survey of accidents with horses. BMF 1973;3:532

13 Chitnavis JP, Gibbons CL, Hirigoyen M, et al. Accidents with horses: what has changed in 20 years. Injury 1996;27: $103-5$
14 British Standards Institute 1972. Protective skull caps for jockeys; Bs4472.

15 Mills NJ, Whitlock MR. Performance of horse-riding helmets in frontal and side impacts. Injury 1989;20:18992

16 British Standards Institute 1988. Protective skull caps for jockeys; Bs4472.

17 British Horse Trials Association Rules Book 1998. Stoneleigh, Warwickshire.

18 British Standards Institute 1994. Protective hats for horse riders; Product Approved Specification (PAS)015.

19 European Committee for Standardisation (CEN) 1994. Helmets for equestrian activities; prEN 1384.

20 British Equestrian Trade Association (BETA) 1991. Protective vests for horse riders.

21 European Committee for Standardisation (CEN)1998. Protective jackets, body and shoulder protectors for horse riders; prEN 13158.

22 Lloyd Parry J. Risks and injuries in horse-riding sports. In: McLatchie G, Lennox ME, eds. Soft tissues: trauma and sports injuries. London: Butterworths, 1993:468-74.

23 British Standards Institution 1998. Helmets for equestrian use: Product Assessment Specification PAS 015; 1998.
Take home message

There is a relatively high risk of sustaining an injury during the cross country phase of eventing. This can be reduced by using PAS 015 helmets and body/shoulder protectors to the prEN 13158 standard.

\title{
The prevalence of chronic knee injury in triathletes
}

\author{
Kirstie Clements, Ben Yates, Michael Curran
}

University College

Northampton, Nene

Centre for Healthcare

Education, Park

Campus, Boughton

Green Road,

Northampton, United

Kingdom

K Clements

B Yates

M Curran

Correspondence to: M Curran, 5 Dover Close, Manor Farm, Rushden, Northants NN10 0RQ United Kingdom.

Accepted for publication 11 February 1999

\begin{abstract}
Objectives-To add to the area of triathlon research by providing much needed prevalence data on knee injury in triathletes.

Method-An incidental "in field" sampling technique was used to interview 58 triathletes aged between 15 and 55 years about knee injury during a triathlon event. The sample comprised 46 men and 12 women.

Results-Most knee injuries occurred during the running event $(72 \%)$ and affected the lateral side of the knee $(38 \%)$. In all, $78 \%$ of the sample sought treatment from a healthcare professional.

Conclusion-The study has provided much needed prevalence data on chronic knee injury in triathletes. (Br f Sports Med 1999;33:214-216)

Keywords: triathlon; knee; Q angle

Triathlon began in Honolulu in 1978 and involves three events, running, cycling, and swimming. According to Williams et $a l,{ }^{1}$ despite ever increasing interest in the sport, research in this area has lagged far behind that into other sports. The amount of literature available detailing aspects of injury and training regimes is small. Studies have focused on incidence of injury, types of injury suffered, and physiological response to swimming, cycling, and running. ${ }^{1-7}$
\end{abstract}

In a study of 72 triathletes by Wilk et $a l{ }^{8}$ three quarters sustained triathlon related musculoskeletal injuries during training as the result of overuse.

Collins et al surveyed 600 finishers in the Seafair Triathlon in 1986 with a $45 \%$ return rate. They reported that $49 \%$ of the respondents suffered a training related injury which caused them to stop training for at least one day. Some $70 \%$ of the injuries were related to running, and the knee, shoulder, and ankle were the most vulnerable. The investigators noted that higher training mileage for swimming, cycling, and running did not lead to a significantly higher incidence of injury.

A study by Korkia et $a l^{10}$ also found that the injury incidence was unrelated to the mean amount of weekly training, competition, intensity, or frequency of training in 155 British triathletes over an eight week period. At least one injury was reported by $58(37 \%)$ of the participants. The most affected areas for these triathletes were the ankle/foot, thigh, knee, lower leg, and back. Most (84\%) of these injuries were minor, and $83 \%$ of the respondents did not have to miss a planned competition.

Ultraendurance triathletes who competed in the 1986 Hawaii Iron Man Triathlon were studied by O'Toole et al. ${ }^{11}$ It was found that $91 \%$ of participants had sustained at least one soft tissue injury during the preceding year, and $84 \%$ of participants reported knee/thigh injuries.

Cipriani et $a l^{12}$ surveyed 118 triathletes and found that knee injuries were the most common. 
Table 1 Location of knee injury in relation to triathlon stage

\begin{tabular}{llll}
\hline Area of knee affected & Run & Cycle & Run and cycle \\
\hline Lateral & 33.3 & 5.5 & 0 \\
Medial & 16.6 & 5.5 & 5.5 \\
Anterior & 11.1 & 5.5 & 0 \\
Anterior/lateral & 11.1 & 0 & 0 \\
Medial/lateral & 0 & 5.5 & 0 \\
Posterior & 0 & 0 & 0
\end{tabular}

Values are percentages.

Only $42 \%$ of the triathletes sought medical treatment, and $43 \%$ had to stop training.

Epidemiology studies noted that most triathlon related injuries occur during run training..$^{8} 101113$

\section{Method}

SUBJECTS

An incidental "in field" sampling technique was used to interview 58 triathletes aged between 15 and 55 years during a triathlon event. The sample comprised 46 men and 12 women.

\section{PROCEDURE}

A structured questionnaire to be administered by an interviewer was designed to assess injuries to the knee sustained during triathlons. The 27 closed ended questions sought to $(a)$ show the prevalence of knee injury within a sample group of triathletes, $(b)$ identify the most common location of knee injury, and (c) determine from which healthcare professionals triathletes sought treatment. Before inclusion in the survey each subject had to meet certain inclusion/exclusion criteria. The inclusion criteria were: aged between 15 and 55; actively training/racing in triathlon for at least one year; participating in all three disciplines; when injury occurred, it was sustained between 1994 and 1997; injury was sustained through training/racing in a triathlon related sport. The exclusion criteria were: previous surgery to the knee; participation in another sport; suffering any debilitating disease. All questions were administered by one of the authors.

\section{DEFINITION OF INJURY}

Injury was defined as any musculoskeletal ailment that caused the athlete to reduce, or refrain from, training for at least two days during the period 1994-1997.

DATA ANALYSIS

To facilitate comparisons, the sample was divided into an injured and non-injured group which were compared using descriptive methods.

\section{Results}

The triathletes sought treatment as follows: $27 \%$ from a physiotherapist; $11 \%$ from a general practitioner; $17 \%$ from a podiatrist; $6 \%$ from a chiropracter/physiotherapist; $17 \%$ from a general practitioner/chiropracter; $22 \%$ did not seek treatment.

The average age was 31 years; $79 \%$ were men and $21 \%$ women. They could be broken down into age groups as follows: aged 15-20, three;
Table 2 A breakdown of injured and non-injured triathletes

\begin{tabular}{lccc}
\hline & $\begin{array}{l}\text { No of } \\
\text { triathletes }\end{array}$ & $\begin{array}{l}\text { No of } \\
\text { injured }\end{array}$ & $\begin{array}{l}\text { No of } \\
\text { non-injured }\end{array}$ \\
\hline Athletic status & 7 & 1 & 6 \\
$\quad$ Novice & 17 & 7 & 10 \\
Club & 26 & 9 & 17 \\
Age group & 7 & 3 & 4 \\
Elite & 1 & 0 & 1 \\
Do not compete & years) & & \\
Duration of participation & 13 & 3 & 10 \\
$>1$ & 20 & 6 & 16 \\
$2-5$ & 16 & 7 & 9 \\
6-8 & 6 & 2 & 4 \\
$9-10$ & 3 & 2 & 1 \\
11+ & & & \\
Running surface & 4 & 1 & 3 \\
Off road & 19 & 5 & 14 \\
Road & 6 & 4 & 2 \\
Grass & 1 & 0 & 1 \\
Treadmill & 28 & 10 & 18 \\
$\quad$ Mixed & & & \\
\hline
\end{tabular}

Table 3 Formal diagnosis of knee injury

\begin{tabular}{ll}
\hline Formal diagnosis & Number of cases \\
\hline Idiopathic & 4 \\
Poor patellae tracking & 4 \\
Iliotibial band friction syndrome & 2 \\
Abnormal pronation & 4 \\
Chondromalacia patellae & 3 \\
Osgood-Schlatters disease & 1 \\
\hline
\end{tabular}

aged 21-25, five; aged 26-30, 23; aged 31-35, 12; aged 36-40, six; aged 41-45, five; aged 46-50, three; aged 51-55, one.

In all, $34 \%(20 / 58)$ of all the athletes interviewed claimed to have suffered a knee injury between 1994 and 1997.

Table 1 shows the prevalence of knee injury, and the area, in relation to the sport. No knee injuries were reported to have occurred during the swimming stage. Cycling produced knee injuries in $22 \%$ (4/18); the lateral, medial, and anterior aspects of the knee were affected. Some $65 \%(13 / 20)$ reported an injury to the knee during the running stage; most of these occurred on the lateral side of the knee. A further $6 \%$ stated that injuries had occurred to their knees through a combination of running and cycling.

Table 2 is a summary of injured and non-injured triathletes.

A previous formal diagnosis of knee injury was made in 18 cases (table 3 ).

\section{Discussion}

A comparison between male and female athletes did not show any large differences. The predominance of male trialthletes compares with other studies. ${ }^{11}$

The average age of the triathletes in the study was 31 years, which is comparable with subjects in a study by Bailey et $a l,{ }^{7}$ but slightly lower than in a study by Massimino et al, ${ }^{6}$ most triathletes in our study being in the 25-30 years bracket $(39 \%)$ and the $30-35$ years group $(21 \%)$.

In all, $78 \%$ of the sample sought treatment in this study, compared with only $51 \%$ in a study by Korkia $e t a l^{4}$ and $42 \%$ in one by Cipriani et $a{ }^{12}$ In both the latter studies treatment was sought primarily from a physiotherapist. However, it should be noted that the time lapse 
between injury and the athlete seeking medical attention was not looked at in our study.

Knee injuries sustained during running were the highest at $72 \%$ compared with $22 \%$ incurred while cycling. These results are comparable with those of Massimino et al ${ }^{6}$ who found that $58 \%$ of knee injuries were caused through running and $20 \%$ by cycling. Cipriani et al. ${ }^{12}$ also found a high incidence of knee injury.

Diagnostic tests were not attempted in this study. Diagnosis was based on what the subject recalled as the diagnosis.

This study found that lateral knee pain had the highest prevalence. This is different from previous studies conducted on runners, in which anterior knee pain was the most common finding. ${ }^{14}{ }^{15}$ Most injuries were sustained through running and affected the lateral side of the knee. Despite the fact that many authors related pain in this area to iliotibial band friction syndrome during long distance running, ${ }^{16-19}$ only two triathletes in our study had been diagnosed with this condition.

The highest number of injuries was observed in athletes who ran on a mixture of terrains $(50 \% ; 10 / 20)$. The group who trained solely on roads or tarmac surfaces accounted for $25 \%$ of the injured athletes. The fact that a large number of athletes remained uninjured despite training only on roads indicates that training on hard surfaces does not always predispose the triathlete to injury.

This study has highlighted the need for further research within the area of multidisciplinary events, in particular the relation between intrinsic and extrinsic factors that predispose to injury.
1 Williams MM, Hawley JA, Black R, et al. Injuries amongst competitive athletes. Physiotherapy in Sport 1988;11:13-15.

2 Manninen JS, Kallien M. Low back pain and other overuse injuries in a group of Japanese triathletes. Br f Sports Med 1996;30:134-9.

3 Ireland M. Patellofemoral disorders in runners and bicyclists. Annals of Sports Medicine 1987;3:77-83.

4 Korkia PK, Tunstall-Pedoe DS, Maffulli N. An epidemiological investigation of training and injury patterns in British triathletes. Br F Sports Med 1994;28:191-6.

5 Collins K, Wagner M, Peterson K, et al. Overuse injuries in triathletes. Am 7 Sports Med 1989;17:675-80.

6 Massimino FA, Armstrong MA, O'Toole ML, et al. Common triathlon injuries: special considerations for multisport training. Annals of Sports Medicine 1988;4:82-6.

7 Bailey M, Dew M, Moore A. A comparative analysis of the incidence of overuse knee injuries in triathletes, runners, and cyclists. Fournal of Therapy and Rehabilitation 1996;3: 537-41.

8 Wilk BR, Fisher KL, Rangelli D. The incidence of musculoskeletal injuries in an amateur triathlete racing club. $\mathcal{F}$ Orthop Sports Phys Ther 1995;22:108-12.

9 Collins K, Wagner M, Peterson K, et al. Overuse injuries in triathletes: a study of the 1986 Seafair Triathlon. $A m \mathcal{F}$ Sports Med. 1989;17:675-80.

10 Korkia PK, Tunstall-Pedoe DS, Maffulli N. An epidemiological investigation of training and injury patterns in British triathletes. Br 7 Sports Med 1994;28:191-6.

11 O'Toole ML, Douglas PS, Hillier B, et al. Overuse injuries in ultraendurance triathlete. Am F Sports Med 1989;17:51418

12 Cipriani DJ, Swartz JD, Hodgson CM. Triathlon and the multisport athlete. F Orthop Sports Phys Ther 1998;27:44-8.

13 Migliorin S. An epidemiological study of overuse injuries in Italian national triathletes in the period 1987-1990. fournal of Sports Traumatology 1991;13:197-206.

14 Brukner P, Khan K. Clinical sports medicine. Sydney: McGraw-Hill, 1993:337-403.

15 La Brier K, O'Neill DB. Patellofemoral stress syndrome. Sports Med 1993;16:449-59.

16 Hutson KS. In: Mellion M, ed. Sports medicine secrets. Philadelphia: Hanley and Belfus, 1994: 60-80.

17 Standish WD, Wood RM. Overuse injuries of the knee. In: Harries M, ed. Oxford textbook of sports medicine. Oxford: Oxford University Press, 1996:568-81.

18 Hutson KS. Other knee conditions. In: Hutson MA, ed. Sports injuries: recognition and management. Oxford: Oxford University Press, 1990:142-8.

19 Hunter S, Dolan MG, Davies JM. Foot orthotics in therapy and sport. Washington DC: Library of Congress Cataloguing In Publication Data, 1995:18-24.

\section{Take home message}

Prevalence data for knee injury in triathletes are provided. Most injuries occurred in the running event and affected the lateral side of the knee. 